\title{
Field Test Program to Develop Comprehensive Design, Operating and Cost Data for Mercury Control Systems on Non-Scrubbed Coal-Fired Boilers
}

\author{
Quarterly Technical Report \\ Reporting Period: October 1, 2001 - December 31, 2001
}

\author{
Principal Authors \\ C. Jean Bustard \\ ADA Environmental Solutions, LLC \\ 8100 SouthPark Way, B-2 \\ Littleton, Colorado 80120 \\ Submitted: January 7, 2002 \\ DOE Cooperative Agreement No.: DE-FC26-00NT41005
}

Report No. 41005R05 


\section{DISCLAIMER}

This technical report was prepared with the support of the U.S. Department of Energy, under Award No. DE-FC26-00NT41005. However, any opinions, findings, conclusions, or recommendations expressed herein are those of the author(s) and do not necessarily reflect the views of the DOE.

This report was prepared as an account of work sponsored by an agency of the United States Government. Neither the United States government nor any agency thereof, nor any of their employees, makes any warranty, express or implied, or assumes any legal liability or responsibility for the accuracy, completeness, or usefulness of any information, apparatus, product, or process disclosed, or represents that its use would not infringe privately owned rights. Reference herein to any specific commercial product, process, or service by trade name trademark, manufacturer, or otherwise does not necessarily constitute or imply its endorsement, recommendation, or favoring by the United States Government or any agency thereof. The views and opinions of authors expressed he rein do not necessarily state or reflect those of the United States Government or any agency thereof. 


\section{ABSTRACT}

With the Nation's coal-burning utilities facing the possibility of tighter controls on mercury pollutants, the U.S. Department of Energy is funding projects that could offer power plant operators better ways to reduce these emissions at much lower costs.

Mercury is known to have toxic effects on the nervous system of humans and wildlife. Although it exists only in trace amounts in coal, mercury is released when coal burns and can accumulate on land and in water. In water, bacteria transform the metal into methylmercury, the most hazardous form of the metal. Methylmercury can collect in fish and marine mammals in concentrations hundreds of thousands times higher than the levels in surrounding waters.

One of the goals of DOE is to develop technologies by 2005 that will be capable of cutting mercury emissions 50 to 70 percent at well under one-half of today's costs. ADA Environmental Solutions (ADA-ES) is managing a project to test mercury control technologies at full scale at four different power plants from 2000 - 2003. The ADA-ES project is focused on those power plants that are not equipped with wet flue gas desulfurization systems.

ADA-ES will develop a portable system that will be moved to four different utility power plants for field testing. Each of the plants is equipped with either electrostatic precipitators or fabric filters to remove solid particles from the plant's flue gas.

ADA-ES's technology will inject a dry sorbent, such as fly ash or activated carbon, that removes the mercury and makes it more susceptible to capture by the particulate control devices. A fine water mist may be sprayed into the flue gas to cool its temperature to the range where the dry sorbent is most effective.

PG\&E National Energy Group is providing two test sites that fire bituminous coals and both are equipped with electrostatic precipitators and carbon/ash separation systems. Wisconsin Electric Power Company is providing a third test site that burns Powder River Basin (PRB) coal and has an electrostatic precipitator for particulate control. Alabama Power Company will host a fourth test at its Plant Gaston, which is equipped with a hot-side electrostatic precipitator and a downstream fabric filter.

During the fifth reporting quarter, progress was made on the project in the following areas:

\section{Alabama Power Company Plant Gaston}

- The team is preparing a paper on the Gaston work that will be submitted for publication in the AWMA EM Journal. The paper includes all the test results and preliminary economics. 


\section{Wisconsin Electric Power Company Pleasant Prairie Power Plant}

- Field testing was completed at the Pleasant Prairie Power Plant during the quarter.

- At the completion of testing, the mercury control system equipment was removed from the Pleasant Prairie Power Plant and moved to PG\&E NEG Brayton Point.

- Started data analysis and reporting.

- Evaluating which ash and coal samples will be submitted for detailed analysis.

\section{PG\&E NEG Brayton Point Station}

- Plans are being made to switch the test schedule for the PG\&E plants. The Brayton Point Station will now be tested in the Spring of 2002 and Salem Harbor will be tested during the Fall of 2002.

- Put together list of potential, alternate sorbent suppliers that we should consider for evaluation at Brayton Point.

- Trying to schedule a time for URS Radian to go to Brayton Point to run slipstream sorbent screening tests. They are available in early February 2002.

- Trying to arrange a planning meeting for the week of January $7^{\text {th }}$.

\section{Technology Transfer}

- Three technical papers on the project were presented during the quarter. 


\section{TABLE OF CONTENTS}

EXECUTIVE SUMMARY ….......................................................... 3

INTRODUCTION

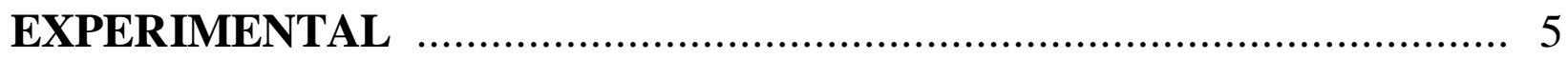

RESULTS AND DISCUSSION .................................................... 6

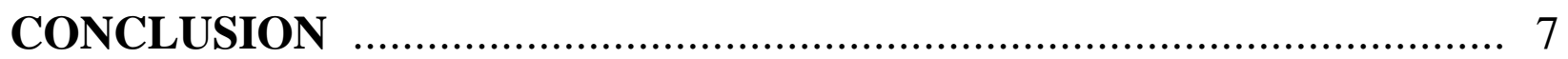

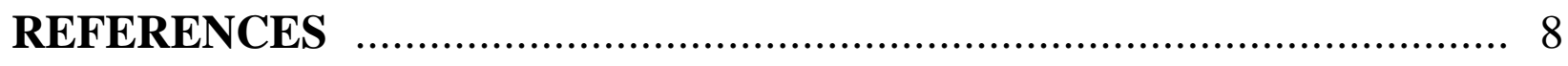

LIST OF ACRONYMS AND ABBREVIATIONS f............................ 9 


\section{LIST OF GRAPHICAL MATERIALS}

There are no graphical materials included in this report. 


\section{EXECUTIVE SUMMARY}

ADA-ES began work on a Cooperative Agreement with the Department of Energy in October, 2000 to demonstrate full-scale mercury control systems at coalfired power plants. The project is the next step in the process of obtaining performance and cost data on full-scale utility plants for mercury control systems. Power generating companies that have entered into contracts with ADA-ES are PG\&E National Energy Group, Wisconsin Electric Power Company and Alabama Power Company. During the three-year, $\$ 6.8$ million project, integrated control systems will be installed and tested at four power plants. ADA-ES is responsible for managing the project including engineering, testing, economic analysis, and information dissemination functions.

On December 14, 2000 the Environmental Protection Agency (EPA) announced that it will be developing regulations for reducing emissions of mercury from coal-fired power plants.

Proposed regulations are expected to be released by December, 2003 and the rules are scheduled to be finalized by December, 2004. It is expected that EPA will include the findings from the ADA-ES/DOE project in its analysis for establishing a mercury control regulation. DOE estimates that the cost to control these emissions will be $\$ 2-\$ 5$ billion annually.

The field test phase of the project began at Alabama Power Company's Plant Gaston during the second reporting quarter. Testing at this site was completed in the third reporting quarter. Sorbent screening testing was completed at Wisconsin Electric's Pleasant Prairie Power Plant during the third reporting quarter and equipment was installed at the site during the fourth reporting quarter. Baseline and parametric testing began during the fourth reporting quarter and the remainder of the field testing was completed during the fifth reporting quarter. The mercury control equipment was removed from the Pleasant Prairie site during the fifth reporting quarter and moved to the PG\&E NEG Brayton Point Station. Prebaseline testing was done at PG\&E NEG's Brayton Point Station during the third quarter and the site was visited during the fourth quarter to scope out modification that will be needed to install testing equipment. Site prep work began during the fourth quarter to accommodate test equipment. Several technical papers were presented on the project during the fifth reporting quarter, and papers will be presented early during the sixth quarter. 


\section{INTRODUCTION}

Cooperative Agreement No. DE-FC26-00NT41005 was awarded to ADA-ES to demonstrate mercury control technologies on non-scrubbed coal-fired boilers. Under the contract, ADA-ES will work in partnership with PG\&E National Energy Group, Wisconsin Electric Power Company, Alabama Power, and EPRI to design and engineer systems to maximize effectiveness and minimize costs to curtail mercury emissions from power plant flue gases. Reports estimate that mercury control could cost the industry from $\$ 2$ to $\$ 5$ billion per year. Much of these costs will be associated with power plants that do not have wet scrubbers as part of their air pollution control configurations. The four plants that will be evaluated during the ADA-ES program are typical of this type of application which is found at $75 \%$ of the nearly 1100 units that would be impacted by new regulations.

Detailed topical reports will be prepared for each site that is tested under the program. Quarterly reports will be used to provide project overviews and technology transfer information. 


\section{EXPERIMENTAL}

Field work was conducted on the project during the fifth reporting quarter at Wisconsin Electric'c Pleasant Prairie Power Plant. Site modifications were started at the Brayton Point Station. Detailed results of the testing at each power plant will be provided in separate topical reports.

\section{Technology Transfer}

Technology transfer activities continued during the fifth reporting quarter of the project. Reference citations of the formal presentations are provided below:

Afonso, R. (2001). "Control Technologies for Reducing Mercury," presented at the New England Section of the A\&WMA meeting, Worcester, MA, October 23.

Durham, M.D. (2001). "Mitigating Mercury Emissions from Western Coals," presented at the Western Coals Transportation Association Annual Meeting, Denver, CO, November 13.

Schlager, R.J. (2001). "Experience with Mercury Control Systems for Boilers Burning Low and Medium Sulfur Coals," presented at the Clean Coal and Power Conference, Washington, D.C., November 19. 


\section{RESULTS AND DISCUSSION}

The major effort during the fifth reporting quarter focused on completing the field testing at the WEPCO Pleasant Prairie Power Plant. Detailed results of the testing at each power plant will be provided in separate topical reports. 


\section{CONCLUSION}

Work began on Cooperative Agreement No. DE-FC26-00NT41005 in October 2000. Initial activities include holding a project kickoff meeting, securing the fourth test site (Alabama Power Company Plant Gaston), and performing various planning and administrative functions. Field testing began during the second reporting period at Plant Gaston, and test planning for the remaining sites began. Test work was completed at the Gaston site during the third reporting period. Site preparations were completed and field testing began at Wisconsin Electric during the fourth reporting period and all site work was completed during the fifth reporting quarter. Technology transfer activities during the quarter and commitments for presenting project information at future meetings have been made. Several new power companies have joined the project team. 


\section{REFERENCES}

None this reporting period. 


\section{LIST OF ACRONYMS AND ABBREVIATIONS}

$\begin{array}{ll}\text { A\&WMA } & \begin{array}{l}\text { Air \& Waste Management } \\ \text { Association }\end{array} \\ \text { DOE } & \text { Department of Energy } \\ \text { EPA } & \begin{array}{l}\text { Environmental Protection } \\ \text { Agency }\end{array} \\ \text { PRB } & \text { Powder River Basin } \\ \text { WEPCO } & \text { Wisconsin Electric Power } \\ & \text { Co. }\end{array}$




\title{
ATTACHMENT A
}

\author{
Accomplishments and Status Assessment \\ October 1, 2001 - December 31, 2001
}

\section{- General}

Final agreements were signed in December 2001 that allow FirstEnergy and Kennecott Energy Co. to participate in the WE portion of the project.

The project is progressing on schedule without any major deviations from plan.

\section{- Alabama Power Company's Plant Gaston}

This facility was the first to be tested in the program. Prebaseline testing was completed in February, 2001 and the parametric test series was performed in March, 2001. The longterm test series was completed during April, 2001. The test facility was decommissioned during May. Economic analysis and topical report were started in June and are continuing. Ontario Hydro test results have been completed. Several questions on coal and ash analysis remain to be resolved.

- WEPCO Pleasant Prairie Power Plant

Sorbent screening testing was completed at Pleasant Prairie in June, 2001. Equipment installations were completed in August, 2001. WEPCO hosted a public site tour of the mercury control system at the end of August as part of the A\&WMA Specialty Conference on Mercury Emissions. Equipment check-out was completed in September and Baseline and Parametric testing began during September 2001. Long-term testing was completed in November, and the mercury control equipment was removed during December and moved to PG\&E NEG Brayton Point.

\section{- PG\&E NEG Salem Harbor Station}

Prebaseline measurements were made at Salem Harbor during February 2001. Mercury emissions measurements were made at the station during July 2001 as required by the state of Massachusetts. Additional prebaseline testing, parametric and long-term testing of Salem Harbor is scheduled for Fall, 2002. Ash samples are being analyzed by Microbeam Technologies and results are being evaluated.

\section{- PG\&E NEG Brayton Point Station}

Prebaseline testing was performed at Brayton Point during June 2001. Mercury emissions measurements were made at the station during the summer of 2001 as required by the state of Massachusetts. The site was visited in July 2001 to evaluate the ductwork, port locations, equipment locations and platform needs. Some site preparation work was done during September 2001. The mercury control equipment was received by the station in December 2001. Parametric and long-term testing of Brayton Point is scheduled for Spring, 2002.

- Technology Transfer

A number of technology transfer activities have taken place since the project began in October 2000. More activities are planned for future conferences, symposia and technical publications. Presentations were made during the quarter at the New England Section of the A\&WMA (October, 2001), the Western Coal Transportation Association meeting (November, 2001), and the DOE Clean Coal and Power Conference (November, 2001). Presentations planned for next quarter include the Fifth Electric Utilities Environmental 
Conference (January, 2002), and the ScienTech Mercury Emissions Workshop (January, 2002). 